\title{
Niemann-Pick disease
}

\author{
Niemann-Pick hastalığı
}

Serap Karaman, Tiraje Celkan

Department of Pediatric Hematology and Oncology, Cerrahpaşa Medical Faculty, İstanbul University, İstanbul, Turkey

The peripheral blood smear is an easy, inexpensive, and very useful diagnostic method. Although some think that it has lost its importance following the development of new automated complete blood counts, the peripheral blood smear should remain a primary diagnostic tool for clinicians, especially pediatricians. Peripheral blood smears aid clinicians in choosing the appropriate laboratory tests for determining definitive diagnoses [1,2].

\section{Case}

A 6-month-old female presented to our clinic with rectal bleeding. On physical examination hepatosplenomegaly was observed. PT and aPTT were prolonged. Her peripheral smear showed lymphocyte vacuolization (Figure 1). Together with hepatosplenomegaly, prolonged PT and aPTT, and elevated ALT and AST, storage diseases were considered in the differential diagnosis. Bone marrow aspiration showed lipid-laden macrophages (Figure 2). The diagnosis of Niemann-Pick disease was confirmed via measurement of lysosomal sphingomyelinase $\left(0.22 \mathrm{nmol} \cdot \mathrm{h} \cdot \mathrm{mg}^{-1} \mathrm{ptn}\right.$ [normal range: 0.86 $2.8]$ ). We have taken informed consent form from the patient.

\section{Discussion}

Lymphocyte vacuolization was noted in our hepatosplenomegaly patient's peripheral blood

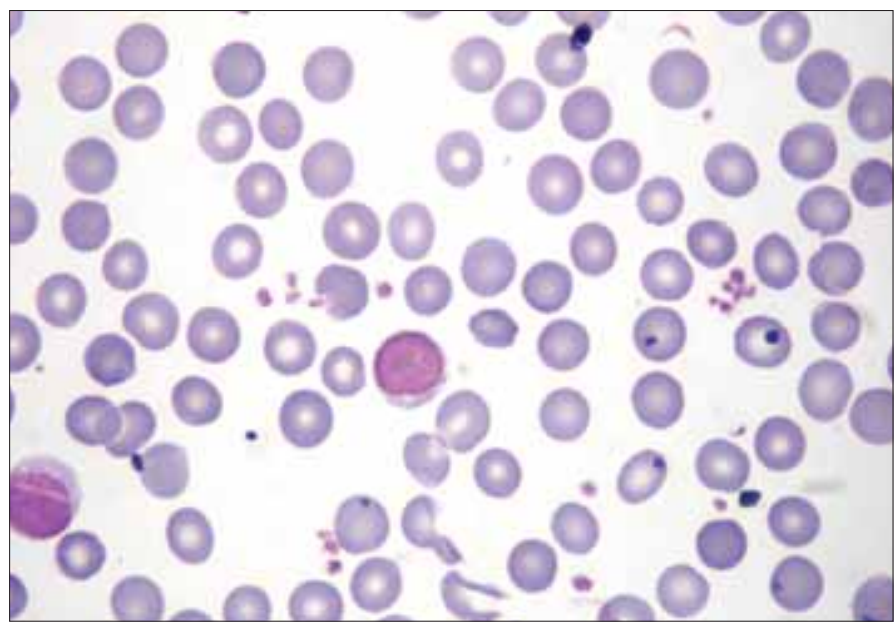

Figure 1. Lymphocyte vacuolization in the patient with NiemannPick disease

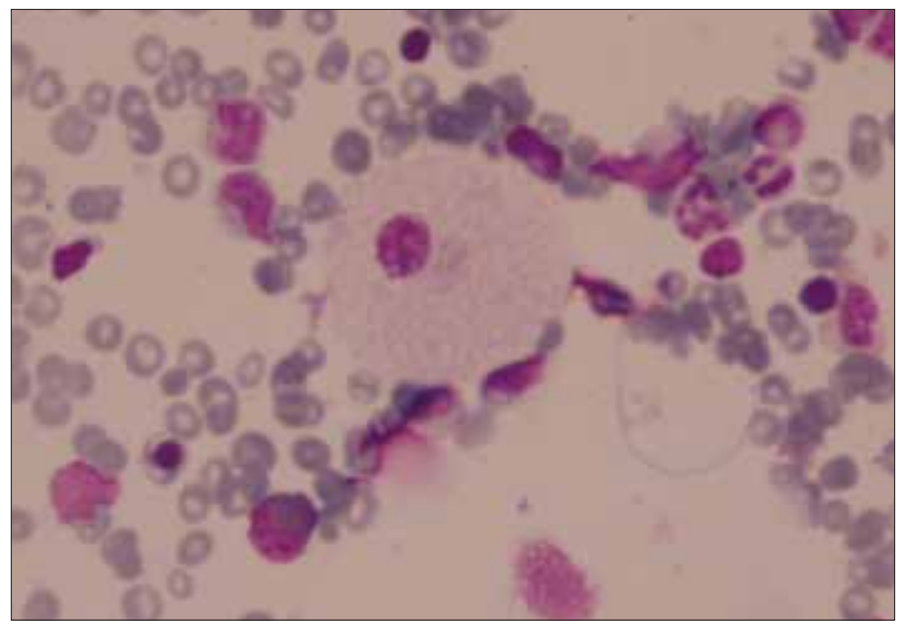

Figure 2. Bone marrow aspiration specimen from the patient with Niemann-Pick disease

Address for Correspondence: M.D. Serap Karaman, Department of Pediatric Hematology and Oncology, Cerrahpaşa Medical Faculty, İstanbul University, İstanbul, Turkey Phone: +90 2126244607 E-mail: drkaramans@yahoo.com 
smear and, therefore, storage diseases were considered in the differential diagnosis. As storage cells were observed in the bone marrow aspiration specimen and lysosomal sphingomyelinase activity was low, the patient was diagnosed with NiemannPick disease.

\section{Conflict of interest statement}

None of the authors of this paper has a conflict of interest, including specific financial interests, rela- tionships, and/or affiliations relevant to the subject matter or materials included.

\section{References}

1. Lewis SM, Bain BJ, Bates I. Practical Haematology. 9 th ed. London:Churcill-Livingstone 2001;19-78.

2. Ezekowitz BA. Hematologic Manifestations of Systemic disease. In: Orkin SH, Nathan DG, Ginsburg D, et al (eds). Hematology and Infancy and Childhood. 7 th ed. Philadelphia:WB Saunders, 2009;pp1679-739. 